\title{
Clinical Features and Maternal-fetal Results of Pregnant Women in COVID-19 Times
}

\section{Características clínicas e resultados materno-fetais de mulheres grávidas com COVID-19}

\author{
Ana Paula Nogueira Godoi ${ }^{1} \quad$ Gilcelia Correia Santos Bernardes ${ }^{1}{ }^{(1)} \quad$ Leilismara Sousa Nogueira $^{10}$ \\ Patrícia Nessralla Alpoim² Melina de Barros Pinheiro ${ }^{10}$
}

1 Universidade Federal de São João del-Rei, Divinópolis, MG, Brazil

2 Universidade Federal de Minas Gerais, Belo Horizonte, MG, Brazil

Rev Bras Ginecol Obstet 2021;43(5):384-394.
Address for correspondence Melina de Barros Pinheiro, PhD, Rua Sebastião Gonçalves Coelho, 400, Bloco D, sala 308.1, Bairro Chanadour, 35501-296 Divinópolis, MG, Brazil (e-mail: melinapinheiro@ufsj.edu.br).

\begin{abstract}
Keywords

- SARS-CoV-2

- COVID-19

- pregnancy

- pregnancy complications

- high risk pregnancy

Objective Coronavirus disease 2019 (COVID-19) is a disease caused by a newly discovered coronavirus, severe acute respiratory syndrome coronavirus 2 (SARSCoV-2), which usually leads to non-specific respiratory symptoms. Although pregnant women are considered at risk for respiratory infections by other viruses, such as SARS and Middle East respiratory syndrome (MERS), little is known about their vulnerability to SARS-CoV-2. Therefore, this study aims to identify and present the main studies on the topic, including the postpartum period.

Methods In this narrative review, articles were searched in various databases, organizations, and health entities using keywords compatible with medical subject headings (MeSH), such as: COVID-19, pregnancy, vertical transmission, coronavirus 2019, and SARS-CoV-2.

Results The review of the scientific literature on the subject revealed that pregnant women with COVID-19 did not present clinical manifestations significantly different from those of non-pregnant women; however, there are contraindicated therapies. Regarding fetuses, studies were identified that reported that infection by SARS-CoV-2 in pregnant women can cause fetal distress, breathing difficulties and premature birth, but there is no substantial evidence of vertical transmission.

Conclusion Due to the lack of adequate information and the limitations of the analyzed studies, it is necessary to provide detailed clinical data on pregnant women infected with SARS-CoV-2 and on the maternal-fetal repercussions caused by this infection. Thus, this review may contribute to expand the knowledge of professionals working in the area as well as to guide more advanced studies on the risk related to pregnant women and their newborns. Meanwhile, monitoring of confirmed or suspected pregnant women with COVID-19 is essential, including in the postpartum period.
\end{abstract}

received

May 6, 2020

accepted

February 4, 2021
DOI https://doi.org/ 10.1055/s-0041-1729145. ISSN 0100-7203.
(C) 2021. Federação Brasileira de Ginecologia e Obstetrícia. All rights reserved.

This is an open access article published by Thieme under the terms of the Creative Commons Attribution License, permitting unrestricted use, distribution, and reproduction so long as the original work is properly cited. (https://creativecommons.org/licenses/by/4.0/)

Thieme Revinter Publicações Ltda., Rua do Matoso 170, Rio de Janeiro, RJ, CEP 20270-135, Brazil 


\section{Resumo}

Palavras-chave
- SARS-CoV-2
- COVID-19
- gravidez
- complicações na
gravidez
- gravidez de alto risco

Objetivo A Coronavirus disease 2019 (COVID-19) é uma doença causada por um coronavírus recém descoberto, o severe acute respiratory syndrome coronavirus 2 (SARSCoV-2), que geralmente leva a sintomas respiratórios não específicos. Embora mulheres grávidas sejam consideradas em risco de infecções respiratórias por outros vírus, como SARS e Middle East respiratory syndrome (MERS), pouco se sabe sobre sua vulnerabilidade ao SARS-CoV-2. Portanto, este estudo tem como objetivo identificar e apresentar os principais estudos sobre o tema incluindo o período pós-parto.

Métodos Nesta revisão narrativa, foram pesquisados artigos em diversas bases de dados, organizações e entidades de saúde, utilizando palavras-chave compatíveis com o MeSH, tais como: COVID-19, gravidez, transmissão vertical, coronavírus 2019, e SARSCoV-2.

Resultados A revisão da literatura científica sobre o assunto revelou que as gestantes com COVID-19 não apresentaram manifestações clínicas significativamente diferentes das não gestantes, porém existem terapias contraindicadas. Em relação aos fetos, foram identificados estudos que relataram que a infecção por SARS-CoV-2 em mulheres grávidas pode causar sofrimento fetal, dificuldades respiratórias e parto prematuro, mas não há evidências substanciais de transmissão vertical.

Conclusão Devido à falta de informações adequadas e às limitações dos estudos analisados, é necessário fornecer dados clínicos detalhados sobre as gestantes infectadas pelo SARS-CoV-2 e sobre as repercussões materno-fetais causadas por esta infecção. Assim, esta revisão pode contribuir para ampliar o conhecimento dos profissionais que atuam na área, bem como para orientar estudos mais avançados sobre o risco relacionado à gestante e seu recém-nascido. Enquanto isso, o monitoramento de gestantes confirmadas ou suspeitas com COVID-19 é essencial, incluindo o pós-parto.

\section{Introduction}

Coronaviruses (CoVs) are a large viral family, known since the mid-1960s, that cause respiratory infections in humans and animals. Some coronaviruses can cause severe respiratory syndromes, such as severe acute respiratory syndrome (SARS) and Middle East respiratory syndrome (MERS). Severe acute respiratory syndrome is caused by the SARS-associated coronavirus (SARS-CoV), with the first reports being made in China in 2002. Middle East respiratory syndrome, in turn, is a respiratory disease caused by the MERS-CoV. It was identified in 2012, and, since 2016, it has been drastically reduced after public health efforts to prevent transmission of MERS-CoV. ${ }^{1,2}$ Recently, a new coronavirus has been identified, SARS-CoV-2, and it is associated with the coronavirus disease 2019 (COVID-19). ${ }^{1,3-5}$

The most common symptoms at onset of COVID-19 illness are fever, cough, and fatigue, while other symptoms include sputum production, dyspnea, headache, hemoptysis, and diarrhea., ${ }^{3,6}$ Some patients with COVID-19 have laboratory changes such as lymphopenia, thrombocytopenia, and elevation of C-reactive protein (CRP). D-dimer elevation can also be identified and serves as an indication of a worse prognosis of COVID-19, although this is already a parameter normally increased in pregnant women. ${ }^{7,8}$ Changes in radiographs are common in symptomatic patients with saturation $<95 \%$, manifesting as pneumonia. ${ }^{7}$
Many patients can be asymptomatic, which facilitates virus spread. ${ }^{7}$ According to the World Health Organization (WHO), on August 10, 2020, there were 19,718,030 people infected globally, with 728,013 confirmed deaths. ${ }^{9}$ In Brazil, on the same date, the number of people infected was $3,035,422$, with 101,049 deaths, ${ }^{10}$ and among these, 199 were puerperal women. ${ }^{11}$

Severe acute respiratory syndrome coronavirus and MERS-CoV have caused adverse maternal-fetal outcomes, such as maternal death, intrauterine fetal growth restriction, spontaneous abortion, and premature birth. Thus, considering that these viruses are similar, as they belong to the same genus Betacoronavirus, one can admit an adverse potential in pregnant women infected with SARS-Cov-2; $;^{3,4,12}$ however, due to its recent discovery, little is known about its relationship with pregnancy. Therefore, this review aimed to analyze reports related to SARS-CoV-2 infection in pregnancy and postpartum as well as its consequences in the maternal-fetal sphere in order to assist in the management of these patients.

\section{Methods}

The PubMed, Scopus, Embase, MedRxiv, Science Direct, and Web of Science databases were searched electronically, as well as the websites for national and international health organizations. 
Only articles published in English and Portuguese were considered. As search strategy, combinations of words related to coronavirus were used, including severe acute respiratory syndrome, SARS, vertical transmission, SARS-CoV-2, COVID-19, and pregnancy, until July 29, 2020.

\section{Results}

\section{Clinical, Laboratory, and Imaging Features in Pregnant} Women with Suspected or Proven COVID-19

It is known that pregnant women have a higher risk of severe morbidity and mortality when affected by other respiratory infections, such as influenza and SARS-CoV. Therefore, they should be considered a population at risk for COVID-19. ${ }^{13-15}$ Adverse maternal-fetal outcomes (e.g. premature birth) have been reported in the literature. However, this information is based on limited data and it is not clear that these results are related to maternal infection. ${ }^{13}$

The Brazilian Ministry of Health included high-risk pregnant women in the risk group for complications caused by SARS-CoV-2 infection. It also emphasizes that urgent measures for specific clinical management must be respected for this population, such as early medication and not delaying radiographic exams regardless of the gestational period. ${ }^{15,16}$ In addition, the possibility of worsening the infection caused by SARS-CoV-2 in pregnant women cannot be ruled out. ${ }^{17}$ The coronavirus clinical management protocol (COVID-19) in primary health care of the Brazilian Ministry of Health has also emphasized the relocation of health professionals who are pregnant, especially if their pregnancy is high-risk. Furthermore, this protocol also establishes that both pregnant and puerperal women should receive priority care. ${ }^{15}$

Therefore, pregnant women with SARS-CoV-2 infection, even with a mild course, should be monitored including bi-monthly fetal growth ultrasound monitoring and Doppler assessment, due to the potential risk of restricted fetal intrauterine growth. ${ }^{18}$ Due to the delay in reverse transcript polymerase chain reaction (RT-PCR) tests, chest computed tomography (CT) in the third trimester may be an effective way to screen for COVID-19 pneumonia in pregnant women, particularly in areas with outbreaks in progress. ${ }^{19}$

In a study by Ellington et al., ${ }^{20}$ data were collected from 91,412 women diagnosed with COVID-19, aged 15 to 44 years, $8.98 \%$ of whom were pregnant. Symptoms were reported by $97.7 \%$ of pregnant women and $96.2 \%$ of non-pregnant women. However, the risk of hospitalization was 5.4 times higher for pregnant women, while the risk of admission to the intensive care unit (ICU) and mechanical ventilation was 1.5 and 1.7 , respectively, compared to the group of non-pregnant women. ${ }^{20}$ In addition to the common laboratory findings in people with COVID-19, all pregnant women with SARS-CoV-2 pneumonia also presented D-dimer levels above the normal range, even considering the normal elevation usually found in pregnancy. Two (29\%) patients had different degrees of abnormal liver function, as well as an increase in alanine aminotransferase (ALT) and/or aspartate aminotransferase (AST). Interleukin-6 was tested in four patients, all with levels above the normal range. Two patients had chronic diseases (polycystic ovaries and hypothyroidism) and three had co-infection (two due to H1N1 and one due to Legionella pneumophila). According to chest computed tomography (CT), $6(86 \%)$ patients had bilateral pneumonia, and the rest (14\%) had unilateral pneumonia. After the follow-up period, all patients were discharged from the hospital. Four neonates were released without testing for SARS$\mathrm{CoV}-2$, and there were no signs of fever or pathological jaundice after 28 days. Three neonates were under observation and were tested, the result was positive in 1 of them 36 hours after birth, even with negative viral tests of cord blood and placenta. The neonate with a positive test did not have a fever or cough, had mild signs of breathing difficulty and a chest X-ray revealed mild pneumonia. After 28 days of life, the baby had two negative results on the molecular test and was discharged. ${ }^{8}$

Wu et al. ${ }^{21}$ evaluated 23 pregnant women with COVID-19, most of whom were asymptomatic $(n=15)$. Among the asymptomatic pregnant women, six were at risk of miscarriage or premature rupture of the membrane. When comparing the average hospital stay, asymptomatic patients had a shorter hospital stay (14 days) than symptomatic patients (25.5 days). ${ }^{21}$

Physiological gestational changes and pathological disorders, such as endocrine and/or vascular disorders, which occur during high-risk pregnancies, may influence the pathogenesis and/or clinical presentation of SARS-CoV-2 infection in pregnant women. ${ }^{22}$ The human placenta expresses an excessive amount of the angiotensin-converting enzyme 2 (ECA2), ${ }^{23}$ which is the SARS-CoV-2 cell receptor, ${ }^{24}$ whose main function is to regulate blood pressure and fetal development. ${ }^{23}$ Thus, a possible intrauterine infection by COVID-19 can alter the ACE2 expression and trigger hypertensive complications during pregnancy, such as preeclampsia. ${ }^{22}$

Hypertensive syndromes are the most frequent complications in pregnancy and are the leading cause of maternal death in Brazil, mainly in its severe forms, such as preeclampsia and hemolysis, elevated liver enzymes, low platelet count (HELLP) syndrome. ${ }^{25}$-Figure 1 shows the most frequent complications in pregnancy.

In a study by Mendoza et al., ${ }^{26} 42$ pregnant women with gestational age greater than 20 weeks and diagnosed with COVID-19 were classified as severe and non-severe according to the type of pneumonia. Eight pregnant women developed severe pneumonia requiring admission to the intensive care unit (ICU), and 6 of these women had characteristics of preeclampsia. When analyzing the criteria for preeclampsia/HELLP syndrome, it was found that only one case had all the requirements (increased lactate dehydrogenase [LDH], placental subperfusion, and abnormal angiogenic state). Thus, the authors suggested that the other 5 cases of preeclampsia can be explained by complications related to COVID-19.26

Although there are few specific data on SARS-CoV-2, other analyzed viruses and respiratory viruses can bring serious conditions to pregnant women and should guide the care of pregnant women with COVID-19 until additional data becomes available. Given the above, the consensus among experts was that pregnant women should be isolated to avoid contamination. ${ }^{1}$ 


\section{Preeclampsia}

- Systolic blood pressure $\geq 140 \mathrm{mmHg}$ and/or diastolic pressure $\geq 90 \mathrm{mmHg}$

- Proteinuria (protein / creatinine ratio) $>0.3$; $>0.1$; on reagent strip test

- Or signs and symptoms: headache and blurred vision.

- Laboratory changes: thrombocytopenia $\left(<100.000 / \mathrm{mm}^{3}\right)$, elevation of liver enzymes and renal impairment

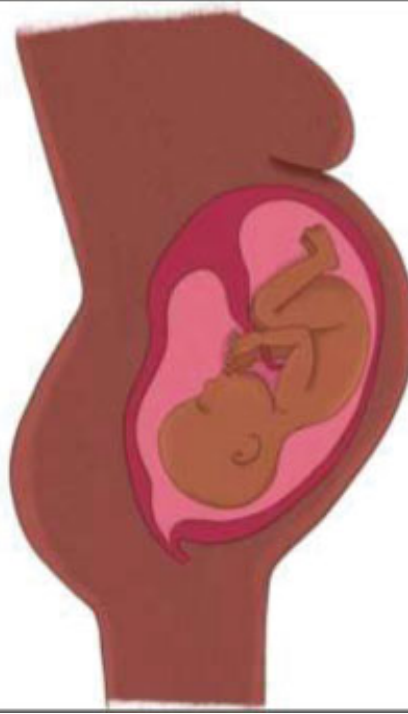

Hellp syndrome

- Hemolysis with high lactate dehydrogenase (LDH)

- $\quad$ AST $\geq 70 U 1 / L$

- Thrombocytopenia: $<100.000 / \mathrm{mm}^{3}$

Fig. 1 Most frequent complications in pregnancy.

According to Zhang et al. (2020), ${ }^{27}$ even the infection with mild symptoms of COVID-19 reduces lung function. Therefore, with early isolation and drug treatment, cases are less likely to progress to severe pneumonia. However, vigilance should be increased, and, if necessary, pregnancy must be interrupted as soon as possible to prevent the development of the disease to severe and critical stages. At the same time, multidisciplinary cooperation is essential to jointly guarantee the safety of the mother-child binomial. ${ }^{27}$

Even during the pandemic, research is conducted on the impacts of COVID-19 infection on the clinical presentation and perinatal and/or puerperal outcomes; however, the data are still limited and are not conclusive regarding the risk of developing severe forms of COVID-19 associated with pregnancy. However, due to the physiological changes of the gestational period, pregnant women can be seriously affected by some infections. Therefore, it is important to adopt precautionary measures against COVID-19 and systematic monitoring of pregnant women, even if this monitoring occurs in the non-face-toface care. - Table 1 shows the findings of the main studies involving pregnant women with COVID-19 and their newborns.

\section{Management of Pregnant Women with COVID-19}

Prenatal and postpartum care cannot be postponed or canceled. Therefore, maternity services must be adapted quickly to provide safe care, minimizing the risk of spreading COVID- 19 . Unfortunately, health services will suffer from lack of professionals, as they also become ill and/or need to isolate themselves during this pandemic period. ${ }^{44,45}$

According to the Brazilian Ministry of Health (2020), ${ }^{46}$ prenatal consultations should take place in a timely manner for pregnant women who do not have flu-like symptoms, paying attention to the prevention of agglomerations and the best hygiene practices. Pregnant women with flu-like symptoms, on the other hand, must have their elective procedures (consultations and routine exams) postponed for 14 days and, when necessary, be seen in an isolated place from other patients. ${ }^{46}$ However, it is worth mentioning that depending on the region of the country, there may be specific guidelines. As an example, in Minas Gerais (Brazil), the State Department of Health stated in a technical note issued on April 1, 2020 that in an area with a high flow due to the COVID-19 pandemic, the flexibility of prenatal consultations at usual risk may occur, at clinical criteria. However, the minimum number of consultations and examinations recommended by the Ministry of Health of Brazil and the World Health Organization must be maintained. ${ }^{47}$

In a randomized, double-blind study conducted in the United States and Canada, the use of hydroxychloroquine as postexposure prophylaxis was evaluated. The participants were divided into two groups, 414 received hydroxychloroquine and 407 received placebo. All participants had home or occupational exposure to patients diagnosed with COVID-19. The results of this study demonstrated that the use of hydroxychloroquine as postexposure prophylaxis has no benefits. ${ }^{48}$

A retrospective cohort study was carried out with 1,438 patients admitted to 25 hospitals in New York to assess the association between hospital mortality caused by SARS-CoV-2 and the use of hydroxychloroquine or azithromycin. The authors concluded that there were no statistically significant differences in mortality between groups. ${ }^{49}$

It is very important to carry out an adequate clinical evaluation, establish criteria and prioritize the use of drugs indicated by the WHO (through the Solidarity study) and the Brazilian Ministry of Health, even if there is still no specific treatment for COVID-19. Other drugs should be used in very severe cases and in the absence of response to therapies. ${ }^{50}$

It is worth mentioning that, for some drugs, there are already more robust reports, but still without solid evidence of use in critically ill patients and not in mild cases. Therefore, caution, equilibrium, and common sense, combined with controlled scientific studies should be used to deal with this pandemic therapeutically. - Tables $\mathbf{2}$ and $\mathbf{3}$ shows the therapies under study against COVID-19 infection. 
388 Clinical Features and Maternal-fetal Results of Pregnant Women in COVID-19 Times Godoi et al.

Table 1 Main results published on pregnant women with COVID-19 and their newborns

\begin{tabular}{|c|c|c|c|c|c|}
\hline $\begin{array}{l}\text { Number of } \\
\text { pregnant } \\
\text { patients }\end{array}$ & Delivery route & Maternal symptoms & $\begin{array}{l}\text { Maternal/fetal complica- } \\
\text { tions }\end{array}$ & Study & $\begin{array}{l}\text { Date of } \\
\text { publication }\end{array}$ \\
\hline 09 & Cesarean section & $\begin{array}{l}\text { Seven patients had fever, } \\
\text { four had cough, and two had } \\
\text { malaise }\end{array}$ & $\begin{array}{l}\text { One had flu, one had gesta- } \\
\text { tional hypertension, one had } \\
\text { pre-eclampsia, two had fetal } \\
\text { distress, and three had a } \\
\text { ruptured membrane }\end{array}$ & $\left(\right.$ Chen et al., 2020) ${ }^{28}$ & March 07, 2020 \\
\hline 17 & Cesarean section & $\begin{array}{l}\text { Four had fever, four had } \\
\text { cough, one had fatigue, two } \\
\text { had chest pain, one had dys- } \\
\text { pnea, and one had diarrhea }\end{array}$ & $\begin{array}{l}\text { Three underwent emergency } \\
\text { cesarean section }\end{array}$ & $(\text { Chen et al., 2020) })^{29}$ & March 16, 2020 \\
\hline 13 & $\begin{array}{l}\text { Ten cesarean sections, five of } \\
\text { which were emergency. } \\
\text { Three pregnant women were } \\
\text { still pregnant at the end of } \\
\text { the study }\end{array}$ & $\begin{array}{l}\text { Ten had fever, three had } \\
\text { dyspnea, and one was } \\
\text { asymptomatic }\end{array}$ & $\begin{array}{l}\text { Three had fetal distress, one } \\
\text { had a ruptured membrane, } \\
\text { and one was stillborn }\end{array}$ & (Liu et al., 2020) $^{30}$ & March 5, 2020 \\
\hline 01 & Spontaneous vaginal & $\begin{array}{l}\text { Fever, cough, headache, and } \\
\text { myalgia }\end{array}$ & $\begin{array}{l}\text { Gestational hypertension } \\
\text { and hypothyroidism. }\end{array}$ & $($ Zambrano et al., 2020) & March 25, 2020 \\
\hline 07 & $\begin{array}{l}\text { Seven cesarean sections, two } \\
\text { of which were emergency } \\
\text { due to preeclampsia }\end{array}$ & $\begin{array}{l}\text { Six had fever, one had cough, } \\
\text { one had shortness of breath, } \\
\text { and one had diarrhea. }\end{array}$ & $\begin{array}{l}\text { Two patients had hyperten- } \\
\text { sion, blurred vision, and } \\
\text { preeclampsia. }\end{array}$ & $\left(\right.$ Yang et al., 2020) ${ }^{32}$ & June 2020 \\
\hline 01 & Vaginal delivery & Fever and dry cough & $\begin{array}{l}\text { Premature rupture of the } \\
\text { membrane }\end{array}$ & $(\text { Xiong et al., 2020) })^{33}$ & April 10, 2020 \\
\hline 01 & Emergency cesarean section & Fever & $\begin{array}{l}\text { Intermittent fever in the } \\
\text { postoperative period. }\end{array}$ & (Wang et al., 2020) $)^{34}$ & March 12, 2020 \\
\hline 23 & $\begin{array}{l}\text { Eighteen cesarean sections, } \\
\text { two vaginal deliveries and } \\
\text { three patients voluntarily } \\
\text { terminated the pregnancy in } \\
\text { the first trimester }\end{array}$ & $\begin{array}{l}\text { Four patients had fever, six } \\
\text { had cough, one had nasal } \\
\text { congestion, and } 15 \text { patients } \\
\text { were asymptomatic }\end{array}$ & $\begin{array}{l}\text { One had fetal intrauterine } \\
\text { hypoxia, two had a ruptured } \\
\text { membrane, four had gesta- } \\
\text { tional hypertension, and } \\
\text { three had threat of } \\
\text { miscarriage }\end{array}$ & $(\text { Wu et al., 2020) })^{21}$ & April 8, 2020 \\
\hline 03 & Vaginal deliveries & $\begin{array}{l}\text { Fever, cough, and chest } \\
\text { tightness }\end{array}$ & No complications & $($ Khan et al., 2020) & March 19, 2020 \\
\hline 04 & $\begin{array}{l}\text { Three cesarean sections and } \\
\text { one vaginal delivery }\end{array}$ & $\begin{array}{l}\text { Three had fever, two had } \\
\text { cough, two had } \\
\text { myalgia/fatigue, and two had } \\
\text { headache }\end{array}$ & $\begin{array}{l}\text { Two newborns had edema } \\
\text { and rash }\end{array}$ & $\left(\right.$ Chen et al., 2020) ${ }^{36}$ & March 16, 2020 \\
\hline 07 & Cesarean & $\begin{array}{l}\text { Six patients had fever, one } \\
\text { had cough, one had short- } \\
\text { ness of breath, and one had } \\
\text { diarrhea }\end{array}$ & $\begin{array}{l}\text { Three patients had uterine } \\
\text { scars }\end{array}$ & $\left(\right.$ Yu et al., 2020) ${ }^{8}$ & March 24, 2020 \\
\hline 15 & $\begin{array}{l}\text { Ten cesarean sections, a } \\
\text { vaginal delivery, and four } \\
\text { patients were still pregnant } \\
\text { at the end of the study }\end{array}$ & $\begin{array}{l}\text { Thirteen had fever, nine dys- } \\
\text { pnea, three myalgia, one di- } \\
\text { arrhea, one cough and one } \\
\text { fatigue }\end{array}$ & Mild clinical manifestations & (Liu et al., 2020) $^{37}$ & July 2020 \\
\hline 01 & Emergency cesarean section & Fever & No complications & (Wang et al., 2020) ${ }^{38}$ & February 28, 2020 \\
\hline 09 & $\begin{array}{l}\text { Seven cesarean sections and } \\
\text { two vaginal deliveries }\end{array}$ & $\begin{array}{l}\text { Eight patients had fever, four } \\
\text { had cough, one had diarrhea, } \\
\text { and one had sore throat }\end{array}$ & $\begin{array}{l}\text { Five neonates were cured, } \\
\text { four remained in the hospital } \\
\text { until the end of the study, } \\
\text { and one died }\end{array}$ & (Zhu et al., 2020) $)^{39}$ & February 09, 2020 \\
\hline 01 & Vaginal delivery & $\begin{array}{l}\text { Fever, chills, dry cough, and } \\
\text { myalgia }\end{array}$ & No complications & (lqbal et al., 2020) & April 01, 2020 \\
\hline 05 & $\begin{array}{l}\text { Three vaginal deliveries, one } \\
\text { cesarean section due to ges- } \\
\text { tational diabetes and one } \\
\text { emergency cesarean section } \\
\text { due to fetal tachycardia }\end{array}$ & $\begin{array}{l}\text { All pregnant women had } \\
\text { postpartum fever }\end{array}$ & $\begin{array}{l}\text { Two patients developed ges- } \\
\text { tational diabetes, and one } \\
\text { developed preeclampsia }\end{array}$ & $(\text { Chen et al., 2020) })^{41}$ & March 28, 2020 \\
\hline 01 & Cesarean section & $\begin{array}{l}\text { Fever, nasal congestion, and } \\
\text { respiratory distress }\end{array}$ & No complications & (Dong et al., 2020) $^{42}$ & March 26, 2020 \\
\hline 02 & Cesarean section & $\begin{array}{l}\text { Two patients had fever, two } \\
\text { had nasal congestion, and } \\
\text { one had chills. One had fever, } \\
\text { nasal congestion, sore } \\
\text { throat, and a rash }\end{array}$ & No complications & $(\text { Fan et al., 2020) })^{43}$ & March 17, 2020 \\
\hline $\begin{array}{l}\text { Case: } 16 \\
\text { COVID-19 }\end{array}$ & Caesarean section & $\begin{array}{l}\text { Fifteen pregnant women } \\
\text { with COVID-19 had mild }\end{array}$ & $\begin{array}{l}\text { One patient in the control } \\
\text { group was in a more serious }\end{array}$ & (Zhang et al., 2020) ${ }^{27}$ & March 25, 2020 \\
\hline
\end{tabular}


Table 1 (Continued)

\begin{tabular}{|c|c|c|c|c|c|}
\hline $\begin{array}{l}\text { Number of } \\
\text { pregnant } \\
\text { patients }\end{array}$ & Delivery route & Maternal symptoms & $\begin{array}{l}\text { Maternal/fetal complica- } \\
\text { tions }\end{array}$ & Study & $\begin{array}{l}\text { Date of } \\
\text { publication }\end{array}$ \\
\hline $\begin{array}{l}\text { pregnant } \\
\text { women } \\
\text { Control: } \\
45 \text { healthy } \\
\text { pregnant } \\
\text { women }\end{array}$ & & $\begin{array}{l}\text { pneumonia, and one of them } \\
\text { had severe pneumonia }\end{array}$ & $\begin{array}{l}\text { condition. No patient in the } \\
\text { case group was in critical } \\
\text { condition }\end{array}$ & & \\
\hline 8.207 & Not informed & $\begin{array}{l}1,799 \text { patients had cough, } \\
1,190 \text { had fever, } 1,323 \text { had } \\
\text { myalgia, } 989 \text { chills, } 1,409 \\
\text { had headache, } 497 \text { had diar- } \\
\text { rhea, } 682 \text { had nausea or } \\
\text { vomiting, } 350 \text { had abdomi- } \\
\text { nal pain, } 326 \text { had runny nose, } \\
\text { and } 587 \text { had new loss of taste } \\
\text { or smell }\end{array}$ & $\begin{array}{l}\text { Risk of hospitalization } 5.4 \\
\text { times higher than non-preg- } \\
\text { nant women. Risk of being } \\
\text { admitted to the ICU and re- } \\
\text { ceiving mechanical ventila- } \\
\text { tion was } 1.5 \text { and } 1.7 \text {, } \\
\text { respectively, compared to } \\
\text { the group of non-pregnant } \\
\text { women }\end{array}$ & (Ellington et al., 2020) & June 26, 2020 \\
\hline
\end{tabular}

Abbreviations: COVID-19, coronavirus disease 2019; ICU, intensive care unit.

Table 2 Drugs recommended by the World Health Organization, in the Solidarity study, for the treatment of COVID-19, on July 6, 2020

\begin{tabular}{|c|c|c|}
\hline Drug & Use in pregnant women & References \\
\hline Remdesivir & $\begin{array}{l}\text { It was not possible to evaluate the effectiveness and/or safety of its use in } \\
\text { pregnant women. The Food and Drug Administration (FDA) has authorized its } \\
\text { compassionate use for the treatment of severe COVID-19 in children and } \\
\text { pregnant women. }\end{array}$ & $\begin{array}{l}\text { (McCoy et al., 2020) } \\
(\text { Lim et al., 2020) }\end{array}$ \\
\hline $\begin{array}{l}\text { Lopinavir/ritonavir } \\
\text { with interferon } \\
\text { beta-1 }\end{array}$ & $\begin{array}{l}\text { It presented a good safety profile in its use in pregnant women. The results of this } \\
\text { study with Interferon beta } 1 \text { suggested that there was no increased risk of } \\
\text { miscarriage or congenital anomalies. }\end{array}$ & $\begin{array}{l}\text { (Tookey et al., 2016) } \\
\text { (Hellwig et al., 2020) }^{54}\end{array}$ \\
\hline
\end{tabular}

Table 3 Drugs recommended by Brazilian Ministry of Health for the treatment of COVID-19

\begin{tabular}{|c|c|c|}
\hline Drug & Use in pregnant women & References \\
\hline Chloroquine & $\begin{array}{l}\text { Chloroquine can induce adverse ophthalmic and } \\
\text { cardiac effects on the fetus. It is also genotoxic. Use } \\
\text { should be carefully assessed. }\end{array}$ & ${\text { (Lacroix et al., } 2020)^{55}}^{5}$ \\
\hline Hydroxychloroquine & $\begin{array}{l}\text { In the treatment of autoimmune diseases, it is not } \\
\text { associated with any increased risk of birth defects, } \\
\text { spontaneous abortions, fetal death, or prematurity. } \\
\text { Hydroxychloroquine can induce adverse ophthalmic } \\
\text { and cardiac effects on the fetus. It is also genotoxic. } \\
\text { Use should be carefully assessed. }\end{array}$ & $\begin{array}{l}\text { (Lacroix et al., 2020; } \\
\text { Sperber et al., 2009) }\end{array}$ \\
\hline Azithromycin & $\begin{array}{l}\text { In most studies, there were no significant associations } \\
\text { between the use of azithromycin in pregnant women } \\
\text { and congenital malformations. }\end{array}$ & (Keskin-Arslan et al., 2020) $^{57}$ \\
\hline
\end{tabular}

\section{Maternal-fetal Care}

According to the United States Center for Disease Control and Prevention (CDC), health professionals should follow some recommendations when performing obstetric procedures in pregnant patients with confirmed or suspected COVID-19 diagnosis, from prehospitalization to discharge of the mother and baby. ${ }^{51-60}$ It is worth mentioning that, in Brazil, the diagnosis in pregnant women must follow the same protocol for the general adult population and that attention should be paid to the signs and symptoms that demonstrate clinical severity. 46
Prehospital care includes notification of the obstetrics unit for the proper delivery room preparation, for the correct use of personal protective equipment (PPE) by the health professionals involved and conduct in accordance with biosafety rules. ${ }^{46}$

During hospitalization, care must be taken to avoid new infections, and newborn isolation should be discussed with health professionals. If the mother expresses the desire to breastfeed, she should be instructed on the precautions to be followed, such as proper hygiene, use of the breast pump or use of a mask, if she chooses to breastfeed. ${ }^{46}$ The benefits of 
390 Clinical Features and Maternal-fetal Results of Pregnant Women in COVID-19 Times Godoi et al.

Table 4 Main studies assessing the possibility of vertical transmission of SARS-CoV-2

\begin{tabular}{|c|c|c|c|c|c|c|c|c|c|}
\hline $\begin{array}{l}\text { Number of } \\
\text { pregnant } \\
\text { women }\end{array}$ & $\begin{array}{l}\text { Age of } \\
\text { pregnant } \\
\text { women }\end{array}$ & $\begin{array}{l}\text { Pregnancy } \\
\text { period }\end{array}$ & $\begin{array}{l}\text { Premature } \\
\text { birth }\end{array}$ & $\begin{array}{l}\text { Average } \\
\text { birth weight }\end{array}$ & $\begin{array}{l}\text { 1-minute } \\
\text { Apgar } \\
\text { score }\end{array}$ & $\begin{array}{l}\text { 5-minute } \\
\text { Apgar } \\
\text { score }\end{array}$ & $\begin{array}{l}\text { Vertical } \\
\text { transmission } \\
\text { signals }\end{array}$ & Study & $\begin{array}{l}\text { Date of } \\
\text { publication }\end{array}$ \\
\hline 1 & 30 years & 35 weeks & One newborn & Not informed & $\begin{array}{l}\text { Not } \\
\text { informed }\end{array}$ & $\begin{array}{l}\text { Not } \\
\text { informed }\end{array}$ & $\begin{array}{l}\text { RT-PCR not } \\
\text { detected }\end{array}$ & (Li et al., 2020) $^{68}$ & $\begin{array}{l}26 \text { de junho } \\
\text { de } 2020\end{array}$ \\
\hline 9 & $26-40$ years & $\begin{array}{l}36-39 \text { weeks } \\
+4 \text { days }\end{array}$ & 4 newborns & $\begin{array}{l}\text { Two newborns had } \\
\text { low birth weight }\end{array}$ & $8-9$ & $9-10$ & $\begin{array}{l}\text { Six newborns } \\
\text { had RT-PCR } \\
\text { undetected at } \\
\text { birth. It was } \\
\text { not possible to } \\
\text { investigate the } \\
\text { other new- } \\
\text { borns at the } \\
\text { time of birth. }\end{array}$ & $\begin{array}{l}\text { (Chen et al., } \\
2020)^{28}\end{array}$ & $\begin{array}{l}\text { March 07, } \\
2020\end{array}$ \\
\hline 17 & $\begin{array}{l}28.7- \\
29.5 \text { years }\end{array}$ & $\begin{array}{l}\text { Three preg- } \\
\text { nant women: } \\
<37 \text { weeks } \\
14 \text { pregnant } \\
\text { women: } \geq 37 \\
\text { weeks }\end{array}$ & $\begin{array}{l}\text { Three } \\
\text { newborns }\end{array}$ & $\begin{array}{l}\text { Not } \\
\text { informed }\end{array}$ & $7-9$ & $9-10$ & $\begin{array}{l}\text { RT-PCR not } \\
\text { detected }\end{array}$ & $\begin{array}{l}\text { (Chen et al., } \\
2020)^{29}\end{array}$ & $\begin{array}{l}\text { March 16, } \\
2020\end{array}$ \\
\hline 13 & $22-36$ years & 25-38 weeks & 6 newborns & $\begin{array}{l}\text { Not } \\
\text { informed }\end{array}$ & $\begin{array}{l}\text { Nine } \\
\text { newborns had } \\
\text { an Apgar } \\
\text { score of } 10\end{array}$ & $\begin{array}{l}\text { Not } \\
\text { informed }\end{array}$ & $\begin{array}{l}\text { RT-PCR not } \\
\text { detected }\end{array}$ & $\begin{array}{l}\text { (Liu et al., } \\
2020)^{30}\end{array}$ & $\begin{array}{l}\text { March 05, } \\
2020\end{array}$ \\
\hline 01 & 41 years & 31 weeks & One newborn & $1,500 \mathrm{~g}$ & $\begin{array}{l}\text { Not } \\
\text { informed }\end{array}$ & $\begin{array}{l}\text { Not } \\
\text { informed }\end{array}$ & $\begin{array}{l}\text { RT-PCR not } \\
\text { detected in } \\
\text { nasopharyn- } \\
\text { geal sample }\end{array}$ & $\begin{array}{l}\text { (Zambrano } \\
\text { et al., 2020) }\end{array}$ & $\begin{array}{l}\text { March 25, } \\
2020\end{array}$ \\
\hline 07 & $\begin{array}{l}\text { Not } \\
\text { informed }\end{array}$ & $36-37$ weeks & $\begin{array}{l}\text { Four late } \\
\text { preterm } \\
\text { infants }\end{array}$ & $2,096 \mathrm{~g} \pm 660 \mathrm{~g}$ & $8-9$ & $9-10$ & $\begin{array}{l}\text { RT-PCR not } \\
\text { detected }\end{array}$ & $\begin{array}{l}\text { (Yang et al., } \\
2020)^{32}\end{array}$ & June 2020 \\
\hline 01 & 25 years & $\begin{array}{l}38 \text { weeks }+4 \\
\text { days }\end{array}$ & No & $3,070 \mathrm{~g}$ & 9 & 10 & $\begin{array}{l}\text { RT-PCR not } \\
\text { detected in } \\
\text { samples of } \\
\text { amniotic fluid, } \\
\text { smear of the } \\
\text { newborn's } \\
\text { throat and } \\
\text { rectum. }\end{array}$ & $\begin{array}{l}\text { (Xiong et al., } \\
2020)^{33}\end{array}$ & $\begin{array}{l}\text { April 10, } \\
2020\end{array}$ \\
\hline 01 & 34 years & 40 weeks & No & $3,205 \mathrm{~g}$ & 8 & 9 & $\begin{array}{l}\text { RT-PCR } \\
\text { detected from } \\
\text { pharynx swab } \\
\text { collected } \\
36 \text { hours after } \\
\text { birth. Cord and } \\
\text { placenta sam- } \\
\text { ples were } \\
\text { negative. }\end{array}$ & $\begin{array}{l}\text { (Wang et al., } \\
2020)^{34}\end{array}$ & $\begin{array}{l}\text { March 12, } \\
2020\end{array}$ \\
\hline 23 & $21-37$ years & $\begin{array}{l}\text { Twenty preg- } \\
\text { nant women: } \\
>28 \text { weeks } \\
3 \text { pregnant } \\
\text { women: < } 12 \\
\text { weeks. }\end{array}$ & $\begin{array}{l}\text { Not } \\
\text { informed }\end{array}$ & $\begin{array}{l}\text { Not } \\
\text { informed }\end{array}$ & $\begin{array}{l}\text { Not } \\
\text { informed }\end{array}$ & $9-10$ & $\begin{array}{l}\text { RT-PCR not } \\
\text { detected in } 04 \\
\text { newborns. The } \\
\text { SARS-CoV-2 in- } \\
\text { fection was } \\
\text { ruled out in the } \\
\text { others using } \\
\text { diagnostic } \\
\text { criteria. }\end{array}$ & $\begin{array}{l}\text { (Wu et al., } \\
2020)^{21}\end{array}$ & $\begin{array}{l}\text { April 08, } \\
2020\end{array}$ \\
\hline 03 & $27-33$ years & $\begin{array}{l}34 \text { weeks }+6 \\
\text { days } \\
39 \text { weeks }+1 \\
\text { day } \\
38 \text { weeks }+2 \\
\text { days. }\end{array}$ & $\begin{array}{l}\text { One } \\
\text { newborn }\end{array}$ & $3,373 \mathrm{~g}$ & $8-9$ & $9-10$ & $\begin{array}{l}\text { RT-PCR not } \\
\text { detected }\end{array}$ & $\begin{array}{l}(\text { Khan et al., } \\
2020)^{35}\end{array}$ & $\begin{array}{l}\text { March 19, } \\
2020\end{array}$ \\
\hline 04 & $28-34$ years & $\begin{array}{l}37 \text { weeks }+2 \\
\text { days } \\
39 \text { weeks } \\
37 \text { weeks }+3 \\
\text { days } \\
38 \text { weeks }+4 \\
\text { days }\end{array}$ & None & $3,400 \mathrm{~g}$ & $7-8$ & $8-9$ & $\begin{array}{l}\text { RT-PCR not } \\
\text { detected in } \\
\text { three new- } \\
\text { borns. The } \\
\text { other parents } \\
\text { did not } \\
\text { authorize. }\end{array}$ & $\begin{array}{l}\text { (Chen et al., } \\
2020)^{36}\end{array}$ & $\begin{array}{l}\text { March 16, } \\
2020\end{array}$ \\
\hline 07 & 29-34 years & $37-41$ weeks & None & g & $8-9$ & $9-10$ & $\begin{array}{l}\text { Four newborns } \\
\text { have not been } \\
\text { tested. Of the } \\
\text { three who } \\
\text { were tested, } \\
\text { one tested } \\
\text { positive } \\
36 \text { hours after } \\
\text { birth }\end{array}$ & $\begin{array}{l}\text { (Yu et al., } \\
2020)^{8}\end{array}$ & $\begin{array}{l}\text { March 24, } \\
2020\end{array}$ \\
\hline 15 & $23-40$ years & $12-38$ weeks & None & $\begin{array}{l}\text { Not } \\
\text { informed }\end{array}$ & 8 & 9 & $\begin{array}{l}\text { RT-PCR not } \\
\text { detected }\end{array}$ & $\begin{array}{l}\text { (Liu et al., } \\
2020)^{37}\end{array}$ & July 2020 \\
\hline 01 & 28 years & 30 weeks & $\begin{array}{l}\text { One } \\
\text { newborn }\end{array}$ & $1,830 \mathrm{~g}$ & 9 & 10 & $\begin{array}{l}\text { RT-PCR not } \\
\text { detected }\end{array}$ & $\begin{array}{l}\text { (Wang et al., } \\
2020)^{38}\end{array}$ & $\begin{array}{l}\text { February } 28, \\
2020\end{array}$ \\
\hline 09 & & $31-39$ weeks & & $2,423 \mathrm{~g}$ & $7-10$ & $8-10$ & & & \\
\hline
\end{tabular}


Table 4 (Continued)

\begin{tabular}{|c|c|c|c|c|c|c|c|c|c|}
\hline $\begin{array}{l}\text { Number of } \\
\text { pregnant } \\
\text { women }\end{array}$ & $\begin{array}{l}\text { Age of } \\
\text { pregnant } \\
\text { women }\end{array}$ & $\begin{array}{l}\text { Pregnancy } \\
\text { period }\end{array}$ & $\begin{array}{l}\text { Premature } \\
\text { birth }\end{array}$ & $\begin{array}{l}\text { Average } \\
\text { birth weight }\end{array}$ & $\begin{array}{l}\text { 1-minute } \\
\text { Apgar } \\
\text { score }\end{array}$ & $\begin{array}{l}\text { 5-minute } \\
\text { Apgar } \\
\text { score }\end{array}$ & $\begin{array}{l}\text { Vertical } \\
\text { transmission } \\
\text { signals }\end{array}$ & Study & $\begin{array}{l}\text { Date of } \\
\text { publication }\end{array}$ \\
\hline & $\begin{array}{l}\text { average } \\
\text { age } 30 \text { years }\end{array}$ & & $\begin{array}{l}\text { Six } \\
\text { newborns }\end{array}$ & & & & $\begin{array}{l}\text { RT-PCR not } \\
\text { detected }\end{array}$ & $\begin{array}{l}\text { (Zhu et al., } \\
2020)^{39}\end{array}$ & $\begin{array}{l}\text { February 09, } \\
2020\end{array}$ \\
\hline 01 & 34 years & 39 weeks & None & $\begin{array}{l}\text { Not } \\
\text { informed }\end{array}$ & 8 & 9 & $\begin{array}{l}\text { RT-PCR not } \\
\text { detected }\end{array}$ & $\begin{array}{l}\text { (lqbal et al., } \\
2020)^{40}\end{array}$ & April 1, 2020 \\
\hline 05 & 25 to years & 38 to 41 weeks & None & g & 10 & 10 & $\begin{array}{l}\text { RT-PCR not } \\
\text { detected }\end{array}$ & $\begin{array}{l}\text { (Chen et al., } \\
2020)^{41}\end{array}$ & $\begin{array}{l}\text { March 28, } \\
2020\end{array}$ \\
\hline 01 & 29 years & $\begin{array}{l}34 \text { weeks + } \\
\text { two days }\end{array}$ & $\begin{array}{l}\text { Not } \\
\text { informed }\end{array}$ & $3,120 \mathrm{~g}$ & 9 & 10 & $\begin{array}{l}\text { RT-PCR not } \\
\text { detected, High } \\
\text { IgM and IgC }\end{array}$ & $\begin{array}{l}\text { (Dong et al., } \\
2020)^{42}\end{array}$ & $\begin{array}{l}\text { March 26, } \\
2020\end{array}$ \\
\hline 02 & $\begin{array}{l}29 \text { and } \\
34 \text { years }\end{array}$ & $\begin{array}{l}36 \text { weeks + } \\
\text { five days } \\
37 \text { weeks }\end{array}$ & $\begin{array}{l}\text { Not } \\
\text { informed }\end{array}$ & $3,145 \mathrm{~g}$ & 9 & 10 & $\begin{array}{l}\text { RT-PCR not } \\
\text { detected }\end{array}$ & $\begin{array}{l}\text { (Fan et al., } \\
2020)^{43}\end{array}$ & $\begin{array}{l}\text { March 17, } \\
2020\end{array}$ \\
\hline 06 & $\begin{array}{l}\text { Not } \\
\text { informed }\end{array}$ & $\begin{array}{l}\text { Not } \\
\text { informed }\end{array}$ & $\begin{array}{l}\text { Not } \\
\text { informed }\end{array}$ & $\begin{array}{l}\text { Not } \\
\text { informed }\end{array}$ & $8-9$ & $9-10$ & $\begin{array}{l}\text { RT-PCR not } \\
\text { detected. In } \\
\text { two newborns } \\
\text { high levels of } \\
\text { IgM and IgG. } \\
\text { And in three } \\
\text { newborns nor- } \\
\text { mal IgM and } \\
\text { elevated IgG. }\end{array}$ & $\begin{array}{l}\text { (Zeng et al., } \\
2020)^{69}\end{array}$ & $\begin{array}{l}\text { March 26, } \\
2020\end{array}$ \\
\hline $\begin{array}{l}\text { Case: } 16 \text { COVID-19 } \\
\text { pregnant women } \\
\text { Control: } 45 \text { healthy } \\
\text { pregnant women }\end{array}$ & $\begin{array}{l}\text { Case: } \\
\text { 24-34 years } \\
\text { Control: } \\
24-40 \text { years }\end{array}$ & $\begin{array}{l}\text { Not } \\
\text { informed }\end{array}$ & $\begin{array}{l}\text { One newborn } \\
\text { from } \\
\text { the case group }\end{array}$ & $\begin{array}{l}\text { Case: } 2,300-3,750 \mathrm{~g} \\
\text { Control: } \\
2,180-4,100 \mathrm{~g}\end{array}$ & $\begin{array}{l}\text { Not } \\
\text { informed }\end{array}$ & $\begin{array}{l}\text { Not } \\
\text { informed }\end{array}$ & $\begin{array}{l}\text { RT-PCR not } \\
\text { detected in } 10 \\
\text { newborns. }\end{array}$ & $\begin{array}{l}\text { (Zhang et al., } \\
2020)^{27}\end{array}$ & $\begin{array}{l}\text { March 25, } \\
2020\end{array}$ \\
\hline
\end{tabular}

Abbreviations: COVID-19, coronavirus disease 2019; lgG, immunoglobulin G; IgM, immunoglobulin M; RT-PCR, reverse transcription polymerase chain reaction; SARS-CoV2, severe acute respiratory syndrome coronavirus 2.

breastfeeding outweigh any potential risks of transmitting the virus through breast milk. ${ }^{25,61}$

The American College of Obstetricians and Gynecologists recommends that doctors should follow the CDC's Interim Clinical Guidelines for the management of patients with confirmed coronavirus disease (COVID-19). ${ }^{13}$ Recommendations are that even if the ideal maternal-newborn care plan is to maintain this binomial, the temporary separation of the newborn from a mother with confirmed or suspected COVID-19 should be strongly considered to reduce the risk of transmission to the newborn. ${ }^{62}$

The WHO recommends that the mother and the newborn should stay together and practice skin-to-skin contact, including hygiene and respiratory care for the mother, especially immediately after birth and during breastfeeding establishment, if the mother or her babies are cases suspected or confirmed of COVID-19. ${ }^{63}$

Delivery routes should be individualized based on the obstetric indications and preferences of the pregnant woman. Cesarean section is ideally performed only when clinically justified. Decisions on the corticosteroids use for fetal pulmonary maturation, emergency childbirth, and termination of pregnancy are challenging conditions and must be based on many factors, such as gestational age, severity of maternal condition, and fetal viability and wellbeing, within a multiprofessional assessment. ${ }^{64,65}$

\section{Vertical Transmission of SARS-Cov-2}

A systematic review article ${ }^{66}$ included 24 studies that analyzed the effects of COVID-19 on pregnant women and newborns. Regarding clinical symptoms, fever was the most common symptom, occurring in $62.9 \%$ of patients, coughing in $36.8 \%$, and sore throat in $22.6 \%$. All deliveries were carried out in a negative pressure room, and care was taken to avoid contamination of the 94 newborns, 31 of whom were premature. The average birth weight was 3,127.6g. Two neonates tested positive for COVID-19. Amniotic fluid, placental fluid, umbilical cord, and gastric juice tested negative. There were three fetal deaths, two due to multiple organ failure and disseminated intravascular coagulation, and the other death because the neonate was cyanotic. No case of severe neonatal asphyxia was observed.

The placenta and decidua are the main interfaces between the mother and the fetus during pregnancy. ${ }^{67}$ And, as already reported, the human placenta expresses $\mathrm{ACE}^{23}$ and, therefore, may be fundamental for the vertical transmission of SARS-CoV-2. ${ }^{22}$ However, the COVID-19 impact on the intrauterine environment is still unclear, as well as whether vertical transmission occurs during a maternal infection. The main studies that have assessed the possibility of vertical transmission are described in - Table 4.

The data to assess the COVID-19 severity in pregnant women are scarce, since most studies had a limited number of participants. It is important to keep in mind that the ideal is to do everything possible to minimize the chance of these patients contracting disease, and, if they do, the measures recommended by the Brazilian Ministry of Health and WHO should be adopted immediately.

\section{Concluding Remarks}

As previously mentioned, studies evaluating the consequences of COVID-19 in pregnant women are scarce and have a limited number of participants, which often generate 
inconclusive data. Clinical manifestations in pregnant women are similar to those of non-pregnant patients, and there is still no scientific evidence of vertical transmission of SARSCoV-2. When confirming or suspecting COVID-19 infection in pregnant women, professional follow-up is essential, and all precautions should be taken to minimize the impacts of the disease. Based on the clinical consequences due to the occurrence of pneumonia of other etiologies during pregnancy, there is a theoretical risk of COVID-19 determining unfavorable fetal repercussions. It is necessary that data on pregnant women infected with SARS-CoV-2 as well as its maternal-fetal repercussions are carefully and thoroughly analyzed and made available during the pandemic. Therefore, more detailed studies and specially designed to assess the effects of COVID-19 on pregnant women and their newborns are mandatory to fill this gap that still exists.

\section{Conflict of Interests}

The authors have no conflict of interests to declare.

\section{Acknowledgments}

This study was financed in part by the Coordenação de Aperfeiçoamento de Pessoal de Nível Superior - Brasil (CAPES) - Finance Code 001.

\section{References}

1 Rasmussen SA, Smulian JC, Lednicky JA, Wen TS, Jamieson DJ. Coronavirus Disease 2019 (COVID-19) and pregnancy: what obstetricians need to know. Am J Obstet Gynecol. 2020;222 (05):415-426. Doi: 10.1016/j.ajog.2020.02.017

2 Wong SF, Chow KM, Leung TN, et al. Pregnancy and perinatal outcomes of women with severe acute respiratory syndrome. Am J Obstet Gynecol. 2004;191(01):292-297. Doi: 10.1016/j. ajog.2003.11.019

3 Schwartz DA, Graham AL. Potential maternal and infant outcomes from Coronavirus 2019-nCoV (SARS-CoV-2) infecting pregnant women: lessons from SARS, MERS, and other human coronavirus infections. Viruses. 2020;12(02):194. Doi: 10.3390/v12020194

4 Zhu N, Zhang D, Wang W, et al; China Novel Coronavirus Investigating and Research Team. A Novel Coronavirus from Patients with Pneumonia in China, 2019. N Engl J Med. 2020;382(08): 727-733. Doi: 10.1056/NEJMoa2001017

5 Wuhan City Health Committee. Wuhan Municipal Health and Health Commission's briefing on the current pneumonia epidemic situation in our city 2019 [Internet]. 2019 [cited 2020 Apr 9]. Available from: http://wjw.wuhan.gov.cn/front/web/showDetail/ 2019123108989

6 World Health Organization. Coronavirus disease (COVID-19): Q\&A [Internet]. 2020 [cited 2020 Mar 25]. Available from: https://www.who.int/news-room/q-a-detail/q-a-coronaviruses

7 Guan WJ, Ni ZY, Hu Y, et al; China Medical Treatment Expert Group for Covid-19. Clinical Characteristics of Coronavirus Disease 2019 in China. N Engl J Med. 2020;382(18):1708-1720. Doi: 10.1056/NEJMoa2002032

8 Yu N, Li W, Kang Q, et al. Clinical features and obstetric and neonatal outcomes of pregnant patients with COVID-19 in Wuhan, China: a retrospective, single-centre, descriptive study. Lancet Infect Dis. 2020;20(05):559-564. Doi: 10.1016/S14733099(20)30176-6

9 WHO Coronavirus Disease (COVID-19) Dashboard [Internet]. 2020 [cited 2020 May 12]. Available from: https://covid19.who.int/
10 Ministério da Saúde. Painel Coronavírus [Internet]. 2020 [cited 2020 May 26]. Available from: https://covid.saude.gov.br/

11 Ministério da Saúde. Secretaria de Vigilância em Saúde. Doença pelo Coronavírus COVID-19. Brasília (DF): Ministério da Saúde; 2020. p. 43. (Boletim Epidemiológico Especial; no. 25)

12 Wong JEL, Leo YS, Tan CC. COVID-19 in Singapore-current experience: critical global issues that require attention and action. JAMA. 2020;323(13):1243-1244. Doi: 10.1001/jama.2020.2467

13 American College of Obstetricians and Gynecologists. Novel Coronavirus 2019 (COVID-19) [Internet]. 2020 [cited 2020 Apr 11]. Available from: https://www.acog.org/clinical/clinical-guidance/practice-advisory/articles/2020/03/novel-coronavirus-2019

14 Qiao J. What are the risks of COVID-19 infection in pregnant women? Lancet. 2020;395(10226):760-762. Doi: 10.1016/S01406736(20)30365-2

15 Ministério da Saúde. Secretaria de Atenção Primária à Saúde (SAPS) Protocolo de manejo clínico do CoronaVírus (COVID-19) na atenção primária à saúde: versão 7. Brasília (DF): Ministério da Saúde; 2020

16 Ministério da Saúde. Secretaria de Atenção Especializada à Saúde. Departamento de Atenção Hospitalar, Domiciliar e de Urgência. Protocolo de manejo clínico da Covid-19 na atenção especializada. Brasíla (DF): Ministério da Saúde; 2020

17 Favre G, Pomar L, Musso D, Baud D. 2019-nCoV epidemic: what about pregnancies? Lancet. 2020;395(10224):e40. Doi: 10.1016/ S0140-6736(20)30311-1

18 Favre G, Pomar L, Qi X, Nielsen-Saines K, Musso D, Baud D. Guidelines for pregnant women with suspected SARS-CoV-2 infection. Lancet Infect Dis. 2020;20(06):652-653. Doi: 10.1016/S1473-3099 (20)30157-2

19 Li N, Han L, Peng M, et al. Maternal and neonatal outcomes of pregnant women with COVID-19 pneumonia: a case-control study. Clin Infect Dis. 2020;71(16):2035-2041. Doi: 10.1093/cid/ciaa352

20 Ellington S, Strid P, Tong VT, et al. Characteristics of women of reproductive age with laboratory-confirmed SARS-CoV-2 infection by pregnancy status - United States, January 22-June 7, 2020. MMWR Morb Mortal Wkly Rep. 2020;69(25):769-775. Doi: 10.15585/mmwr.mm6925a1

21 Wu X, Sun R, Chen J, Xie Y, Zhang S, Wang X. Radiological findings and clinical characteristics of pregnant women with COVID-19 pneumonia. Int J Gynaecol Obstet. 2020;150(01):58-63. Doi: 10.1002/ijgo.13165

22 Jing Y, Run-Qian L, Hao-Ran W, et al. Potential influence of COVID19/ACE2 on the female reproductive system. Mol Hum Reprod. 2020;26(06):367-373. Doi: 10.1093/molehr/gaaa030

23 Pringle KG, Tadros MA, Callister RJ, Lumbers ER. The expression and localization of the human placental prorenin/renin-angiotensin system throughout pregnancy: roles in trophoblast invasion and angiogenesis? Placenta. 2011;32(12):956-962. Doi: 10.1016/j.placenta.2011.09.020

24 Zhou P, Yang XL, Wang XG, et al. A pneumonia outbreak associated with a new coronavirus of probable bat origin. Nature. 2020;579 (7798):270-273. Doi: 10.1038/s41586-020-2012-7

25 Mariani Neto C. Nótula complementar sobre COVID-19 e aleitamento materno [Internet]. 2020 [cited 2020 May 26]. Available from: www.febrasgo.org.br/pt/noticias/item/949-notula-complementar-sobre-covid-19-e-aleitamento-materno

26 Mendoza M, Garcia-Ruiz I, Maiz N, et al. Pre-eclampsia-like syndrome induced by severe COVID-19: a prospective observational study. BJOG. 2020;127(11):1374-1380. Doi: 10.1111/1471-0528.16339

27 Zhang L, Jiang Y, Wei M, et al. [Analysis of the pregnancy outcomes in pregnant women with COVID-19 in Hubei Province]. Zhonghua Fu Chan Ke Za Zhi. 2020;55(03):166-171. Doi: 10.3760/cma.j. cn112141-20200218-00111 Chinese

28 Chen H, Guo J, Wang C, et al. Clinical characteristics and intrauterine vertical transmission potential of COVID-19 infection in nine pregnant women: a retrospective review of medical records. 
Lancet. 2020;395(10226):809-815. Doi: 10.1016/S0140-6736 (20)30360-3

29 Chen R, Zhang Y, Huang L, Cheng BH, Xia ZY, Meng QT. Safety and efficacy of different anesthetic regimens for parturients with COVID-19 undergoing Cesarean delivery: a case series of 17 patients. Can J Anaesth. 2020;67(06):655-663. Doi: 10.1007/ s12630-020-01630-7

30 Liu Y, Chen H, Tang K, Guo Y. Clinical manifestations and outcome of SARS-CoV-2 infection during pregnancy. J Infect. 2020; •*: S0163-4453(20)30109-2. Doi: 10.1016/j.jinf.2020.02.028 [ahead of print.]

31 Zambrano LI, Fuentes-Barahona IC, Bejarano-Torres DA, et al. A pregnant woman with COVID-19 in Central America. Travel Med Infect Dis. 2020;36:101639. Doi: 10.1016/j.tmaid.2020.101639

32 Yang $P$, Wang $X$, Liu $P$, et al. Clinical characteristics and risk assessment of newborns born to mothers with COVID-19. J Clin Virol. 2020;127:104356. Doi: 10.1016/j.jcv.2020.104356

33 Xiong X, Wei H, Zhang Z, et al. Vaginal delivery report of a healthy neonate born to a convalescent mother with COVID-19. J Med Virol. 2020;92(09):1657-1659. Doi: 10.1002/jmv.25857

34 Wang S, Guo L, Chen L, et al. A case report of neonatal 2019 Coronavirus Disease in China. Clin Infect Dis. 2020;71(15): 853-857. Doi: 10.1093/cid/ciaa225

35 Khan S, Peng L, Siddique R, et al. Impact of COVID-19 infection on pregnancy outcomes and the risk of maternal-to-neonatal intrapartum transmission of COVID-19 during natural birth. Infect Control Hosp Epidemiol. 2020;41(06):748-750. Doi: 10.1017/ ice.2020.84

36 Chen Y, Peng H, Wang L, et al. Infants born to mothers with a New Coronavirus (COVID-19). Front Pediatr. 2020;8:104. Doi: 10.3389/ fped.2020.00104

37 Liu D, Li L, Wu X, et al. Pregnancy and perinatal outcomes of women with Coronavirus Disease (COVID-19) pneumonia: a preliminary analysis. AJR Am J Roentgenol. 2020;215(01): 127-132. Doi: 10.2214/AJR.20.23072

38 Wang X, Zhou Z, Zhang J, Zhu F, Tang Y, Shen X. A case of 2019 Novel Coronavirus in a pregnant woman with preterm delivery. Clin Infect Dis. 2020;71(15):844-846. Doi: 10.1093/cid/ciaa200

39 Zhu H, Wang L, Fang C, et al. Clinical analysis of 10 neonates born to mothers with 2019-nCoV pneumonia. Transl Pediatr. 2020;9 (01):51-60. Doi: 10.21037/tp.2020.02.06

40 Iqbal SN, Overcash R, Mokhtari N, et al. An uncomplicated delivery in a patient with Covid-19 in the United States. N Engl J Med. 2020;382(16):e34. Doi: 10.1056/NEJMc2007605

41 Chen S, Liao E, Cao D, Gao Y, Sun G, Shao Y. Clinical analysis of pregnant women with 2019 novel coronavirus pneumonia. J Med Virol. 2020;92(09):1556-1561. Doi: 10.1002/jmv.25789

42 Dong L, Tian J, He S, et al. Possible vertical transmission of SARSCoV-2 from an infected mother to her newborn. JAMA. 2020;323 (18):1846-1848. Doi: 10.1001/jama.2020.4621

43 Fan C, Lei D, Fang C, et al. Perinatal transmission of COVID-19 associated SARS-CoV-2: should we worry? Clin Infect Dis. 2020; ...:ciaa226. Doi: 10.1093/cid/ciaa226 [ahead of print]

44 Poon LC, Yang H, Lee JCS, et al. ISUOG Interim Guidance on 2019 novel coronavirus infection during pregnancy and puerperium: information for healthcare professionals. Ultrasound Obstet Gynecol. 2020;55(05):700-708. Doi: 10.1002/uog.22013

45 Cheyne H. Pregnant during the coronavirus crisis? Don't panic [Internet]. 2020 [cited 2020 May 26]. Available from: https:// theconversation.com/pregnant-during-the-coronavirus-crisisdont-panic-135108

46 Ministério da Saúde. Secretaria de Atenção Primária à Saúde. Departamento de Ações Programáticas Estratégicas. Coordenação-Geral de Ciclos da Vida. Coordenação de Saúde das Mulheres. Nota Técnica no. 7/2020-COSMU/CGCIVI/DAPES/SAPS/MS: trata das orientações a serem adotadas na atenção à saúde das gestantes no contexto da pandemia do novo coronavírus (SARS-CoV2) [Internet]. 2020 [cited 2020 Apr 16]. Available from: https:// portaldeboaspraticas.iff.fiocruz.br/biblioteca/gestantes-notatecnica-no-6-2020-cosmu-cgcivi-dapes-saps-ms/

47 Secretaria de Estado de Saúde de Minas Gerais. Centro de Operações de Emergência em Saúde. Nota Técnica COES Minas COVID-19 no. 19/2020, de 1 de abril de 2020. Orientações ao atendimento de gestantes e puérperas no cenário de enfrentamento da doença do Coronavírus (COVID-19) [Internet]. 2020 [cited 2020 Apr 26]. Available from: https://www.saude.mg.gov.br/images/noticias_e_eventos/000_2020/Coronav\%C3\%ADrus/Nota_T\%C3\%A9cnica_COES_n \%C2\%BA_19.pdf

48 Boulware DR, Pullen MF, Bangdiwala AS, et al. A randomized trial of hydroxychloroquine as postexposure prophylaxis for Covid-19. N Engl J Med. 2020;383(06):517-525. Doi: 10.1056/NEJMoa2016638

49 Rosenberg ES, Dufort EM, Udo T, et al. Association of treatment with hydroxychloroquine or azithromycin with in-hospital mortality in patients with COVID-19 in New York State. JAMA. 2020; 323(24):2493-2502. Doi: 10.1001/jama.2020.8630

50 Ministério da Saúde. Secretaria de Ciência, Tecnologia, Inovação e Insumos Estratégicos em Saúde. Departamento de Gestão e Incorporação de Tecnologias e Inovação em Saúde. Coordenação-Geral de Gestão de Tecnologias em Saúde. Coordenação de Gestão de Protocolos Clínicos e Diretrizes Terapêuticas. Diretrizes para diagnóstico e tratamento da COVID-19. Brasília (DF): Ministério da Saúde; 2020

51 McCoy JA, Short WR, Srinivas SK, Levine LD, Hirshberg A. Compassionate use of remdesivir for treatment of severe coronavirus disease 2019 in pregnant women at a United States academic center. Am J Obstet Gynecol MFM. 2020;2(03):100164. Doi: 10.1016/j.ajogmf.2020.100164

52 Lim S, DeBruin DA, Leider JP, et al. Developing an ethics framework for allocating remdesivir in the COVID-19 pandemic. Mayo Clin Proc. 2020;95(09):1946-1954. Doi: 10.1016/j.mayocp.2020.06.016

53 Tookey PA, Thorne C, van Wyk J, Norton M. Maternal and foetal outcomes among 4118 women with HIV infection treated with lopinavir/ritonavir during pregnancy: analysis of populationbased surveillance data from the national study of HIV in pregnancy and childhood in the United Kingdom and Ireland. BMC Infect Dis. 2016;16:65. Doi: 10.1186/s12879-016-1400-y

54 Hellwig K, Duarte Caron F, Wicklein EM, Bhatti A, Adamo A. Pregnancy outcomes from the global pharmacovigilance database on interferon beta-1b exposure. Ther Adv Neurol Disorder. 2020; 13:1756286420910310. Doi: 10.1177/1756286420910310

55 Lacroix I, Bénévent J, Damase-Michel C. Chloroquine and hydroxychloroquine during pregnancy: What do we know? Therapie. 2020;75(04):384-385. Doi: 10.1016/j.therap.2020.05.004

56 Sperber K, Hom C, Chao CP, Shapiro D, Ash J. Systematic review of hydroxychloroquine use in pregnant patients with autoimmune diseases. Pediatr Rheumatol Online J. 2009;7:9. Doi: 10.1186/15460096-7-9

57 Keskin-Arslan E, Kaplan YC, Koren G. Use of azithromycin during pregnancy and breastfeeding: a coronavirus pandemic (COVID19) update. Motherisk Int J.. 2020;1:12

58 World Health Organization. "Solidarity" clinical trial for COVID19 treatments [Internet] 2020 [cited 2020 Apr 12]. Available from: https://www.who.int/emergencies/diseases/novel-coronavirus-2019/global-research-on-novel-coronavirus2019-ncov/solidarity-clinical-trial-for-covid-19-treatments

59 Ministério da Saúde. Orientações do Ministério da Saúde para manuseio medicamentoso precoce de pacientes com diagnóstico da COVID-19. Brasília (DF): Ministério da Saúde; 2020

60 Centers for Disease Control and Prevention. Interim considerations for infection prevention and control of Coronavirus Disease 2019 (COVID-19) in inpatient obstetric healthcare settings [Internet]. 2020 [cited 2020 Apr 02]. Available from: https://www. cdc.gov/coronavirus/2019-ncov/hcp/guidance-for-ems.html

61 Davanzo R, Mosca F, Moro G, Sandri F, Agosti M. Allattamento e infezione da SARS-CoV-2 (Coronavirus Disease 2019 - COVID-19) 
394 Clinical Features and Maternal-fetal Results of Pregnant Women in COVID-19 Times Godoi et al.

[Internet]. 2020 [cited 2020 Apr 26]. Available from: https:// www.policlinico.mi.-

it/uploads/fom/attachments/pagine/pagine_m/79/files/allegati/ 539/allattamento_e_infezione_da_sars-cov-2_indicazioni_ad_interim_della_societ__italiana_di_neonatologia_sin__2_pdf

62 Centers for Disease Control and Prevention. Evaluation and management considerations for neonates at risk for COVID-19 [Internet]. 2020 [cited 2020 Jul 25]. Available from: https:// www.cdc.gov/coronavirus/2019-ncov/hcp/caring-for-newborns. html

63 World Health Organization. Breastfeeding and COVID-19 [Internet]. 2020 [cited 2020 Jul 25]. Available from: www.who.int/news-room/ commentaries/detail/breastfeeding-and-covid-19

64 World Health Organization. Clinical management of severe acute respiratory infection when COVID-19 is suspected [Internet]. 2020 [cited 2020 Jul 25]. Available from: https://apps.who.int/iris/bitstream/handle/10665/331446/WHO-2019-nCoV-clinical-2020.4-eng.pdf?sequence $=1$ \&isAllowed $=\mathrm{y}$
65 World Health Organization. WHO statement on caesarean section rates [Internet]. 2015 [cited 2020 May 10]. Available from: https:// www.who.int/reproductivehealth/publications/maternal_perinatal_health/cs-statement/en/

66 Matar R, Alrahmani L, Monzer N, et al. Clinical presentation and outcomes of pregnant women with COVID-19: a systematic review and meta-analysis. Clin Infect Dis. 2020;•••:ciaa828. Doi: $10.1093 /$ cid/ciaa828 [ahead of print]

67 Li M, Chen L, Zhang J, Xiong C, Li X. The SARS-CoV-2 receptor ACE2 expression of maternal-fetal interface and fetal organs by singlecell transcriptome study. PLoS One. 2020;15(04):e0230295. Doi: 10.1371/journal.pone.0230295

$68 \mathrm{Li}$ Y, Zhao R, Zheng S, et al. Lack of vertical transmission of severe acute respiratory syndrome Coronavirus 2, China. Emerg Infect Dis. 2020;26(06):1335-1336. Doi: 10.3201/eid2606.200287

69 Zeng H, Xu C, Fan J, et al. Antibodies in infants born to mothers with COVID-19 pneumonia. JAMA. 2020;323(18):1848-1849. Doi: $10.1001 /$ jama.2020.4861 